\title{
Korean Pop sebagai Identitas Subkultur iKONIC
}

\author{
Vania P. Hanjani ${ }^{1}$, Amirudin Amirudin², Mulyo Hadi Purnomo \\ ${ }^{1}$ Pasca Sarjana Magister Antropologi, Fakultas Ilmu Sosial dan Politik, Universitas Indonesia \\ ${ }^{2}$ Program Studi Antropologi, Fakultas Ilmu Budaya, Universitas Diponegoro, Indonesia \\ Email : vaniahanjani22@gmail.com, amdjtg@yahoo.com
}

\begin{abstract}
The popularity of Korean Pop culture can be used as a reference for adolescents to become a spear of maturity which ends in the formation of a subculture. We will discuss about how young people who gradually follow the development of $i K O N$, a boygroup. They are willing to set aside most of the money they get, in order to fulfill their desire for satisfaction for iKON. iKON is a famous South Korean boy group that is currently very admired. This group has even won many awards and managed to become one of the closing guest stars of the well-known sports festival named ASIAN GAMES 2018 with their song Rhythm Ta and Love Scenario. With this phenomenon, more and more teenagers have decided to become iKONIC, an iKON fan community.This ethnographic and qualitative research will address the symbolic theory of interpretivism by Clifford Geertz which explains that culture is a system of regularity of meanings and symbols. With this meaning, each individual will communicate, establish, and develop knowledge about life as well as addressing life. Like teenagers who are members of the iKONIC community, they learn, receive and share the symbols from iKON. iKONIC will make iKON as a reference in doing everything in their lives. iKONIC is willing to buy many items related to iKON such as albums, merchandise, streaming passes, and even concert tickets that are very expensive. The more they are fond of the presence of $i K O N$, the more they cling to the principles instilled by iKON. Their daily habits in imitating, accessing information continuously, result in their own dependence on them. The occurrence of many processes such as social contact, cultural understanding, the cognition system which became a symbol system, then shared, this is the reason existence of habits that continue to occur to become a culture for the iKONIC. So that a subculture is formed in the midst of a culture that has become widespread and entrenched.
\end{abstract}

Keywords : Sub-Culture, Korean Pop, iKON, iKONIC, Indentity

\section{Pendahuluan}

Remaja dalam perkembangannya untuk menjadi dewasa mengalami banyak proses pembentukan yang panjang, termasuk yang paling berpengaruh adalah kebudayaan. Sebuah kebudayaan menjadi suatu penggerak untuk melaksanakan aktifitas, norma dan nilai yang berkembang.

Spradley (1997:5) mengutarakan pendapatnya mengenai kebudayaan. Dia menyatakan :

"pengetahuan yang diperoleh, yang digunakan orang untuk menginterpretasikan pengalaman dan melahirkan tingkah laku sosial." 
Dari kebudayaan yang besar, memiliki beberapa bagian sub yang bisa disebut dengan subkultur, yang terbentuk karena adanya kebiasaan baru yang biasanya condong kepada hasil dari pengungkapan identitas baru dari budaya yang besar. Seperti Korean Pop atau kebudayaan K-Pop yang sengaja dibuat untuk segera diterima massa luas demi keentingan pembuat serta semua pihak yang memassakannya. K-Pop yang termasuk kedalam budaya pop sendiri telah mempengaruhi banyak kalangan remaja hingga mengeluh-eluhkan idolanya. Contohnya yang terjadi pada $i K O N I C$, pada masa remaja tersebut, mereka dengan sangat antusias untuk mengikuti keseharian para idolanya dan terus mengikuti perkembangan yang ada.

Idola menjadi bagian penting dalam kebudayaan remaja, ini karena bisa dikatakan tidak ada remaja yang tidak memiliki idola (Suprayogi, 1998). Keadaantransisi remaja menuju kedewasa, sosok idola menjadi suatu identitas kesenangan untuk mereka, dan bahkan hal tersebut tidak dapat dipisahkan.

Idola merupakan bentuk paling jelas dari kebudayaan pop dan tempat berbagai macam gaya dan citra dipresentasikan (Defleur dan Everette, 1985:353). Para $i K O N I C$ yang menggemari $i K O N$ tentu saja melihat sang idola tersebut sebagai sebuah fenomena yang menarik mereka dari berbagai segi. Penampilan, bakat, tarian, suara, dan visualnya.

\section{Metode}

Penelitian mengguankan metode kualitatif yang berlaku dalam studi antropologi. Secara khusus, metode kualitatif dalamn antropologi dikenal dengan metode etnografi, yakni suatu cara yang dipakai bagaimana peneliti (etnografer) mengkaji daan menukan suatu kebudayaan yang berlaku dalam suatu satuan sosial. Dalam konteks ini, satuan sosial adalah kelompok budaya "ikonik", yakni suatu subkultur baru bentukan "Korean Pop". Mereka, para ikonik yang tergabung dalam subkultur baru itu, learn and share terhadap proses berbudaya yang dilakukan Koren Pop. Untuk itu, guna keperluan menemukan kebudayan baru mereka dilakukan dengan pengamatan dari dekat, wawancara (deskriptif, kontras, dan struktur), hingga didapatkan sistem budaya yang berlaku membentuk identitas subkultur baru itu.

\section{Hasil dan Pembahasan}

\subsection{Budaya Pop dan Perkembangan K-Pop di Indonesia}

Permulaan budaya pada kehidupan manusia di ciptakan dari hasil interaksi antara manusia dengan segala isi yang ada di alam raya. Kebudayaan bisa di katakan sebagai hasil ciptaan manusia, dan manusia sendiri hidup di antaranya. Budaya akan terus hidup dan berkembang mana kala manusia masih ada di dalamnya. Kegunaan budaya pun beragam, contohnya suatu budaya ada sebagai pedoman interaksi antar manusia maupun kelompoknya, wadah untuk menyalurkan perasaan-perasaan dan kemampuan-kemampuan yang di miliki, petunjuk manusia agar memiliki batasan bertindak dan menentukan sikap. Budaya pun seiring dengan waktu akan terus berubah dan fleksibel mengikuti perkembangan zaman dan juga kegunaannya dalam kehidupan dan juga bergantung dengan perubahan dari masyarakat itu sendiri.

Perubahan perilaku masyarakat yang mengikuti alur perkembangan zaman mengakibatkan perubahan budaya, sehingga memproses pengertian budaya semakin kompleks dan juga budaya populer. Budaya kini tidak bisa di lepaskan dari kepentingan ekonomi, politik, dan produksi budaya 
oleh kapitalis. Terlihat dari pemasaran musik yang berujung kepada pemungutan biaya pada setiap pembelian lagu ataupun dalam pembelian album.

Budaya populer didominasi dengan produksi dan juga konsumsi barang-barang material atau/dan bukan seni-seni sejati, manakala penciptanya didorong oleh motif laba. Budaya populer disokong oleh industri budaya yang telah mengkontruksi masyarakat, tidak sekedar berlandaskan konsumsi tapi menjadikan artefak budaya sebagai produk industri dan komuditi terutama juga dalam hal kepuasan (Ibrahim, 2006).

Budaya populer sendiri bisa berkembang dengan baik dan cepat didukung dengan adanya media massa. Budaya populer berkembang sebagai akibat dari kemudahan-kemudahan reproduksi yang diberikan oleh teknologi seperti internet, percetakan, fotografi, perekaman suara, dan sebagainya (Malthy dalam Barker: 20:37).

Salah satu budaya yang turut mempengaruhi perkembangan budaya populer ialah budaya pop Korea atau yang lebih dikenal sebagai K-Pop atau Hallyu Wave atau juga Korean Wave. Fenomena Korean Wave atau demam Korea mengacu pada popularitas budaya Korea di luar negeri yang mencakup hiburan seperti drama, musik pop, animasi, games, dan lain sebagainya. Indonesia sendiri menjadi negara dengan dampak besar oleh Korean Wave ini dikarenakan Indonesia masih masuk dalam kategori negara berkembang yang mudah dipengaruhi oleh budaya luar terutama budaya populer. Penyebaran Korean Wave sendiri ditunjang dengan adanya media massa yang memfasilitasi seperti televisi dan internet (Puspitasari, 2013).

Korean Wave ini sendiri tidak hanya menyuguhkan hiburan berupa drama dan musik, Korean Wave menawarkan pula seperti bentuk make up, fashion, dan kuliner. Korean Wave muncul setelah Korea memasuki tahap diplomasi dengan Republik Rakyat Tiongkok (RRT) pada tahun 1992. Korean Wave pertama kali menyebar pada tahun 1996 yaitu pada saat boygroup seperti H.O.T, Baby Vox, dan the National Ballet Company masuk ke dalam pasar Tiongkok, dan kemudian disusul dengan penayangan drama Korea di televisi. Istilah Korean Wave pertama kali dikenalkan oleh media massa Tiongkok, yaitu Qingnianbao pada tahun 1999, untuk menujukkan kepopuleran hiburan Korea yang berkembang pesat di negara tersebut (Hae Joang, 2005).

Menyebarnya Korean Wave ke berbagai kalangan di dunia memunculkan berbagai komunitas penggemar atau fans dari berbagai negara. K-Pop memiliki banyak penggemar setia yang terbagi dalam fandom-fandom sesuai dengan artisnya masing-masing dengan tingkat kefanatikan yang tinggi. Fandom adalah istilah yang digunakan untuk menunjuk pada subkultur, berbagai hal dan berbagai kegiatan yang berkenaan dengan penggemar dan kegemarannya. Contohnya boygroup iKON dengan nama fandom iKONIC (Hollow, 2000).

Fandom merupakan subkultur yang menawarkan sebuah ruang untuk komunitas yang memungkinkan semua kalangan masyarakat beragam untuk membentuk kesatuan dalam minat yang sama. Kamunitas ini membuat seseorang dengan minat khusus merasa bahwa dirinya tidak sendirian. Fandom menciptakan sebuah ruang agar anggotanya bisa saling mengekspresikan diri mereka dengan leluasa. Para penggemar ditampilkan sebagai salah satu hal yang dianggap berbahaya dalam kehidupan modern. Mereka lebih terobsesi dan histeris kepada idola yang mereka puja, penggemar tersebut tidak bisa menciptakan jarak batas antara diri sendiri dan objek kesenangannya.

Masyarakat pada zaman sekarang terutama untuk para remaja tidak dapat memungkiri bahwa demam K-Pop memang sudah tersebar luas. Masuknya idol K-Pop ke ranah Indonesia membuat remaja seakan-akan terhipnotis untuk terus mengikuti perkembangan idolnya. Sejak 2000-an, boygroupdan girlgroup Korea banyak berbondong-bondong mengadakan konser di Indonesia. 
Bahkan pada saat ini penyanyi K-Pop yang datang ke Indonesia bisa sepuluh kelompok lebih tiap tahunnya.

Adanya K-Pop yang merajahi masyarakat Indonesia terutama pada kaum remaja mengakibatkan tingkat konsumsi konten K-Pop berkembang pesat. Hal tersebut menandakan bahwa tingkat fanatisme menjadi semakin tinggi. Mereka terkumpul menjadi satu kesatuan kelompok yang memiliki kecenderungan dan kesamaan hobi.

Identitas sendiri tidak hanya memberikan makna tentang pribadi seseorang, tapi lebih jauh dari itu menjadi ciri khas sebuah kebudayaan yang melatar belakanginya. (Liliweri, 2002:68). Dari ciri khas tersebutlah setiap orang dapat dikenali dan bahkan dapat diketahui hobi dan kesukaannya.

Dari sisi etimologis, kata identitas berasal dari identity yang berarti kondisi tentang sesuatu yang sama atau sesuatu yang mirip satu sama lain, kondisi atau fakta tentang sesuatu yang sama antara dua orang atau juga bisa dua benda, dan kondisi atau fakta yang menggambarkan sesuatu yang sama diantara individu berbeda atau bahkan kelompok berbeda (Liliweri, 2002).

Identitas sendiri menandakan bahwa seorang individu ataupun sebuah kelompok pasti memiliki ciri khas, kebudayaan dan tingkah laku yang mereka lakoni setiap hari yang hampir sama bahkan bisa dikatakan sama. Sebagai bentuk wujud nyata identitas kebudayaan.

Identitas budaya adalah sebuah rincian karakteristik atau ciri-ciri sebuah kebudayaan yang dimiliki oleh sekelompok orang yang diketahui batas-batasnya saat dibandingkan dengan karakteristik dari kebudayaan orang lain. (Arif, 2013:28). Berarti jika seseorang ingin mengetahui dan menetapkan identitas budaya, maka tidak hanya berputar pada penentuan karakteristik dan ciri fisik atau biologis semata, tapi juga mengkaji mengenai tata cara berfikir, perasaan, dan cara bertindak dengan motivasi di baliknya.

Identitas budaya dapat diartikan sebagai suatu ciri yang membedakan suatukelompok bahkan individu. Setiap kelompok pasti memiliki budaya sendiri atau bahkan sebuah suku bangsa. Contohnya di Indonesia, salah satu negara yang memiliki banyak suku bangsa dengan ciri ragam budaya yang berbeda. Hal itulah yang membuat suatu kelompok bisa dibedakan dari kelompok lainnya.

Kemunculan fandom dari berbagai idola K-Pop mengakibatkan munculnya sebuah komunitas baru yang didirikan untuk suatu tujuan tertentu. Hal inilah yang kemudian memicunya kemunculan subkultur, arus globalisasi yang ditandai semakin dinamisnya perkembangan kebudayaan akibat adanya gelombang pertukaran antar-bangsa, dan yang dimaksud disini adalah Korea-Indonesia.

Menurut John Storey, konsumsi atas suatu budaya populer akan selalu memunculkan adanya kelompok penggemar, bahwa "penggemar adalah bagian paling tampak dari khalayak teks dan praktik budaya pop" (John Storey, 2007:157). Musik K-Pop sendiri mampu menciptakan banyak fans dari berbagai macam fandom yang berasal dari berbagai macam idol. Contohnya datang dari VIP yang merupakan nama fandom dari BIGBANG, EXO-L untuk EXO, ARMY untuk BTS, dan lain sebagainya.

Begitu pula pada $i K O N I C$, yang merupakan nama fandom penggemar dari iKON. Mereka memiliki sejumlah kegiatan yang tentunya sangat berkaitan dengan idolnya, yang menyebabkan fandom tersebut memiliki sebuah kebiasaan dan ciri khas. Kebiasaan dan ciri khas tersebut menjadi suatu budaya tersendiri, sehingga menjadikan mereka sebagai subkultur seperti fandom-fandom lainnya. Identitas subkultur $i$ KONIC terlihat dari kegiatan yang mereka lakoni setiap hari yang menjadikan diri mereka memiliki suatu ciri khas tersendiri.

Kemungkinan-kemungkinan yang bisa terjadi disini adalah aktifitas yang mereka lakukan akan mengganggu aktifitas pokok keseharian mereka, dan bahkan bisa saja mereka terlalu terfokus 
pada $i K O N$ hingga menelantarkan kebutuhan mereka sendiri. Atau pula muncul keingin tahuan bagaimana bisa mereka menjadi suatu subkultur dan seberapa fokusnya mereka untuk mendukung $i K O N$.

iKON sendiri merupakan salah satu boygroup terkenal dibawah naungan sebuah agensi besar bernama $Y G$ Entertainment. Agensi ini merupakan satu dari tiga agensi hiburan terbesar di Korea Selatan bersama dengan SM Entertainment dan JYP Entertainment.Anggota boygroup tersebut adalah Kim Hanbin (B.I), Kim Jinhwan(Jay), Kim Jiwon (Bobby), Song Yunhyeong (Song), Goo Junhoe (June), Kim Donghyuk (DK), dan Jung Chanwoo (Chan) yang mengalami masa trainee atau pelatihan dalam kurun waktu yang berbeda-beda.

$i K O N$ menjadi salah satu grup yang sangat terkenal dan berhasil memikat banyak penggemar. $i K O N$ telah menjadi produk budaya populer karena disukai secara luas oleh banyak orang (Storey, 1994). Kepopuleran iKONdi pasar musik mampu membuktikan bahwa mereka merupakan boygroup yang berbakat dengan lagu-lagu yang mampu diterima oleh khalayak umum.

Dengan adanya kesuksesan $i K O N$ yang mendunia tentunya akan menarik para penggemarnya untuk terus setia mengikuti perkembangan $i K O N$ dan menjadikan $i K O N$ sebagai sistem budaya mereka hingga membentuk sebuah identitas untuk subkultur $i$ KONIC.

\subsection{Korean Pop dan Identitas $i K O N I C$ : dari "Model of" Menjadi "Model for" Anak-anak Muda Perkotaan}

Anak-anak muda perkotaan mengalami enkulturasi budaya dari budaya global berupa Korean Pop (K-Pop) melalui proses share (berbagi) and learn (belajar) secara bersama-sama, hingga akhirnya terintegrasi ke dalam satuan sosial yang sama-sama mengalami, menjalani, dan mewujudkannya kedalam tindakan kolektif - menjadi iKONIC.

Proses share and learn yang mereka alami tentu rumit karena proses enkulturasi bermula dari bagaimana mereka melakukan interaksi atau kontak budaya, memasukan kompleksitas budaya K-Pop ke dalam skema kognisi, hingga mewujudkannya ke dalam bentuk-bentuk simbol yang diyakini, diikuti dan dikomunikasikan ke yang lain, sampai pada akhirnya system symbol ikut tertanam dan menjadi acuan tingkah laku kolektif mereka. Bertolak dari sini, pelukisan mendalam mengenai bagaimana anak-anak muda mengalami enkulturasi K-Pop akan dimulai dari deskripsi bagaimana mereka mengalami kontak dan interaksi dengan budaya K-Pop hingga akhirnya iKONIC menjadi identitas cultural mereka.

\subsubsection{Awal Mula Menjadi $i K O N I C$}

Para remaja perkotaan mengenal $i K O N$ melalui banyak cara yang ada, penunjang terbesarnya adalah media. Media memiliki peran yang sangat besar dalam penyebaran segala informasi yang akan berpengaruh satu sama lain termasuk berpengaruh kepada ketertarikan seseorang yang akan berpotensi membentuk subkultur. Kesamaan selera musik, kepribadian dari para anggota $i K O N$, bakat, visual dan aspek-aspek lainnya menarik perhatian para kaum remaja untuk tertarik pada $i K O N$. Keterikatan emosi yang kuat juga menjadi sebuah pengaruh besar pada iKONIC dalam rasa cintanya terhadap $i K O N$. 


\subsubsection{Fanatisme Kaum $i K O N I C$ pada $i K O N$}

Menurut John Storey (2007: 157), konsumsi atas suatu budaya populer akan selalu memunculkan adanya kelompok penggemar. Dia mengatakan bahwa penggemar adalah bagian paling tampak dari khalayak teks dan praktik budaya pop. Fans sendiri merupakan cerminan dari sang artis, semakin banyak fans maka bisa dikatakan semakin besar pula kepopuleran artis yang mereka dambakan.

Penggemar sendiri digambarkan oleh Jenkins sebagai individu yang tengah melakukan sebuah bentuk pembaruan suatu makna atau produk budaya. Permaknaan tersebut adalah sebuah tindakan bebas yang melibatkan intelektual dan juga emosi. Manusia memiliki hasrat untuk mencari dan memaknai budaya dalam rangka membentuk identitas dirinya, dan penggemar adalah sekumpulan orang yang tertarik pada suatu produk budaya hingga menimbulkan rasa ingin memiliki secara penuh kemudian mengekspresikannya pada kehidupan sehari-hari (Jenkins, dalam Storey, 2007:163).

Para penggemar memiliki intensitas keterlibatan emosi dan juga intelektual serta memberi makna kepada produk budaya. Konsumsi budaya sendiri berkaitan erat dengan pemaknaan individu akan pola yang ingin dia bentuk sebagai identitas diri, dan dari banyaknya budaya yang ditawarkan, semakin banyak pula gaya hidup yang diyakini dapat membentuk identitas juga memberikan simbol-simbol tertentu. Dari situlah seorang individu menjadi dapat dikenali oleh orang lain.

Konsumsi atas budaya populer termasuk pada K-Pop juga telah berhasil melahirkan penggemar di seluruh dunia. K-Pop mampu membentuk sebuah dunia baru bagi penggemarnya, menghasilkan nilai-nilai baru, dan juga trend baru yang mampu diikuti pula oleh banyak orang setiap grup pasti memiliki penggemar yang memiliki sebutan fandom masing-masing dan juga memiliki ciri khas atau simbolnya masing-masing. Termasuk juga iKONIC yang merupakan penggemar dari boygroup iKON.

Simbol budaya populer seperti $i K O N$ adalah suatu yang dipentaskan, dipanggungkan, disebarluaskan dalam berbagai gambaran, dan kan karena itu maknanya ditafsirkan oleh pikiran yang diberikan pada kita (Irianto, 2009:91). Seringkali boygroup menjadi simbol anak-anak muda saat ini (milenial) untuk mereka dapat berkomunikasi langsung melalui konser yang diselenggarakan maupun melalui media massa. iKONIC menjadi sebuah simbol subkultur dengan identitas yang mereka miliki dan juga simbol atribut yang mereka gunakan. Contohnya KONBAT yang merupakan sebuah lightstick penanda simbol identitas secara fisik bahwa mereka merupakan salah satu anggota dari $i K O N$.

\subsubsection{Usaha $i K O N I C$ Demi Cintanya Terhadap $i K O N$}

Selain cerita mengenai asal muasal para $i K O N I C$ bisa terjun dalam dunia K-POP dan memilih $i K O N$ sebagai idola mereka, terdapat juga beberapa kisah yang membuat mereka rela untuk bekerja bahkan menabung demi iKON. Mereka rela memangkas jatah makan, jatah berbelanja, menyumbang sebagaian penghasilan untuk event yang mengatas namakan $i K O N$ dan lain-lain hanya untuk memuaskan diri dengan segala hal yang berkaitan dengan iKON. Mereka juga bahkan rela untuk meluangkan sebagian besar waktunya untuk sekedar meng-update informasi mengenai $i K O N$.

Event tersebut seperti berupa sumbangan ke panti, perlindungan satwa liar, sumbangan uang secara Cuma-Cuma diatas namakan untuk iKON. Seperti contohnya komunitas komunitas iPROJECT, merupakan perkumpulan iKONIC yang mendedikasikan diri secara penuh untuk mengurus event yang berkaitan dengan $i K O N$ seperti streaming musik berbayar, vidio, buybulk, dan 
lain-lain yang tentu saja kadang kala Medina harus membayar uang secara suka rela demi kelangsungan event.

Antusiasme $i K O N I C$ juga ditunjukkan saat konser $i K O N$ berlangsung. Mereka terbiasa datang di pagi buta untuk mengantri masuk ke dalam venue, demi berada di barisan paling depan, padahal konser dimulai pada pukul 6 malam. Tak khayal banyak bentuk-bentuk antusiasme yang terjadi saat konser berlangsung seperti penyamaan atribut, yel-yel, berbagi merchandise, dan lainlain.

Tentunya penyamaan atribut antar $i K O N I C$ atau pembelian merchandise memberikan rasa kepuasan emosional tersendiri, seperti yang dikatakan oleh Storey, budaya pop mengekspresikan kesulitan remaja dalam menghadapi permasalahan emosional dan menjadi dorongan keamanan emosional mereka yang tidak pasti. Budaya pop bagaikan padang rumput yang subur di tengah gurun bagi para remaja yang tentu saja dalam arti dapat melegakan kepuasan emosi mereka (Storey, 2007:125).

\subsection{3. iKON sebagai Inspirasi}

Selain mengenai taktik para $i K O N I C$ untuk terus mengusahakan diri datang ke konser dan memiliki merchandise resmi dari $i K O N$, terdapat juga cerita mengenai keterkaitan emosi $i K O N I C$ yang menyebabkan mereka selalu terikat dengan $i K O N$ dan tidak dapat berpaling sedikitpun. Selain lagu yang berkualitas, mereka memiliki kepribadian yang baik, para member juga terkenal dengan ketaatan mereka dalam beribadah terutama Donghyuk dan Bobby. Bahkan mereka juga menghargai perbedaan agama satu sama lain.

Pembelajaran yang $i K O N$ berikan secara sengaja maupun tidak di sengaja membuat para iKONIC menjadikan mereka inspirasi dalam bertindak dan juga berkepribadian. Hal tersebut membuat mereka memiliki prinsip dan acuan dalam bertindak.

\subsubsection{Twitter sebagai Rumah Informasi $i K O N I C$}

Sistem budaya merupakan wujud yang abstrak dari kebudayaan. Sistem budaya atau cultural system merupakan ide-ide dan gagasan manusia yang hidup bersama dalam suatu masyarakat. Fungsi sistem budaya adalah menata dan memantapkan tindakan-tindakan serta tingkah laku manusia (Sulaeman, 2012).

Sistem budaya menjadikan suatu kaum memiliki ciri khas sendiri termasuk juga pada fans KPop yang memiliki ide, simbol, bahasa dan fanatismenya. Adanya fanatisme para $i K O N I C$ terhadap iKON membuat mereka memiliki kebiasaan, ciri khas, dan bahkan kebudayaan yang mereka miliki sendiri. Kebiasaan sehari-hari yang mereka lakukan menjadi sebuah keharusan yang berdampak terus-menerus. Ditunjang dengan keadaan Indonesia yang merupakan negara berkembang yang sangat mudah untuk dipengaruhi oleh budaya-budaya dari negara maju termasuk Korea Selatan (Puspitasari, 2015).

\subsubsection{Perilaku Keseharian $i K O N I C$}

Sistem budaya yang terbentuk antara $i K O N$ dan $i K O N I C$ tidak lepas dari keseharian yang mereka jalani baik $i K O N$ maupun $i K O N I C$ itu sendiri. $i K O N$ yang sangat mempengaruhi hanya hidup $i K O N I C$ dan sebaliknya $i K O N I C$ yang menunjang kesuksesan untuk $i K O N$. Fanatisme sendiri menjadi sebuah bentuk pengekspresian diri $i K O N I C$ dalam mencintai $i K O N$. Fanatisme sendiri 
menjadi sebuah anggapan pada orang umum sebagai bentuk yang berlebihan, sedangkan dari sisi iKONIC sendiri memandang bahwa fanatisme yang mereka lakoni menjadi suatu bentuk pengekspresian diri yang selayaknya.

Perlakuan para $i K O N I C$ pada kesehariannya seperti cara mereka dalam mengakses media untuk mengetahui perkembangan keseharian $i K O N$, berinteraksi dengan sesama $i K O N I C$ dan bahkan juga berinteraksi langsung dengan sang idola yaitu $i K O N$ membuat suatu keterkaitan satu sama lain yang melatar belakangi terjadinya kesamaan rasa, kesukaan, tingkah laku, ide, simbol, selera dan lain-lain yang kemudian semakin lama akan membentuk sebuah sistem budaya.

Keterkaitan emosi juga turut berperan sangat besar dalam keadaan ini, guna mempertahankan $i K O N I C$ untuk tetap setia pada sang idola. Sang idola yaitu $i K O N$ juga memiliki beberapa taktik keterikatan emosi seperti melakukan komunikasi yang intens dengan penggemar, menciptakan lagu yang benar-benar di khususkan untuk sang penggemar dan juga melakukan siaran live.

Adanya keterkaitan emosi seperti contoh di atas merupakan salah satu faktor utama dari munculnya fanatisme berlebih kepada sang idola, fanatisme tersebut berlangsung sehari-hari yang menyebabkan menjadi suatu kebiasaan untuk para penggemar. $i K O N$ sendiri menanamkan pendidikan moral kepada para penggemarnya seperti memberikan nasihat dan lain-lain sehingga para $i K O N I C$ pun memiliki sebuah pedoman perilaku yang baik pula. Contohnya di saat $i K O N$ memberitahu bahwa para iKONIC harus mendahulukan kepentingan mereka sebelum memperhatikan $i K O N$ atau contoh perilaku seperti saat salah satu member $i K O N$ yaitu Bobby, menyebrangkan jalan untuk seorang nenek, saat Yunhyeong dan Jinhwan mengikuti kampanye perlindungan anak dan wanit, juga di saat konser berlangsung, mereka mengutus pada penggemar yang beragama muslim untuk beribadah terlebih dahulu saat waktunya sudah tiba.

Perilaku-perilaku $i K O N$ seperti di atas secara tidak langsung akan mempengaruhi pola pikir, tindakan, kebiasaan pada para penggemarnya. Dari situlah $i K O N$ tidak hanya menjadikan $i K O N I C$ sebagai objek penggemar tetapi juga menanamkan hal-hal baik yang harus di contoh. Melalui semua hal tersebut mengakibatkan terciptanya sistem budaya lekat pada para $i$ KONIC.

\section{4. iKONIC sebagai Identitas}

Praktik yang telah iKONIC laksanakan baik dalam kesehariannya maupun pada project tertentu seperti konser dan fanmeeting telah menggambarkan bagaimana proses terbentuknya sebuah identitas. Dari sini iKONIC menajadi salah satu contoh ciri khas sebuah subkultur. Melalui ciri khas tersebut seseorang dapat menemukan darimana atau komunitas apa individu itu berasal.

Identitas tersebut sendiri dihasilkan melalui proses bersosialisasi maupun juga dapat terpengaruh oleh kebudayaan yang ada. Identitas budaya adalah rincian karakteristik atau ciri sebuah kebudayaan yang dimiliki oleh sebuah kelompok yang diketahui batas dan perbedaannya di kala ciri dan karakteristiknya dibedakan dengan kelompok budaya lainnya. Hal itu juga berarti jika seseorang memiliki keinginan untuk mengetahui dan menetapkan identitas budaya, maka tidak semata mengacu pada ciri fisik yang terlihat, tetapi juga mengkaji identitas tersebut dari segi cara berfikir, bertindak dan bahkan perasaan atau keterikatan emosi (Liliweri, 2007).

Identitas sendiri dinilai sangat penting karena membantu masyarakat luas untuk bisa mengenal individu atau kelompok baik dalam segi agama, budaya, atau bahkan politik. Identitas tersebut juga menjadi sebuah simbol untuk menandai suatu golongan. $i K O N I C$ dalam pemikirannya sendiri memegang identitas dan simbol yang selalu melekat untuk dapat membedakan komunitasnya 
dengan komunitas yang lain. Simbol yang mereka dapatkan diperoleh dari sebuah pencarian makna yang mereka lakukan demi sang idola.

Dikatakan oleh Irianto (2009) bahwa manusia adalah hewan pencari makna, berupaya mengungkapkan cara-cara simbolik yang secara individual dan kelompok memberi makna pada kehidupan. Simbol sendiri berarti sebuah sesuatu yang disebar luaskan, dipertontonkan dan di panggungkan.

Simbol yang dipertontonkan oleh $i K O N$ akan diterima baik oleh para iKONIC yang kemudian dipraktikkan dalam kehidupan sehari-hari. Mereka menuangkan norma dan menyebarluaskan simbol yang ada. Hal tersebut juga didongkrak oleh $i K O N$ sendiri sebagai suatu simbol perwujudan utama dari iKONIC. iKONIC tercipta karena adanya $i K O N$ yang menyebarluaskan simbol yang mereka miliki, kemudian mengundang terbentuknya suatu komunitas atau subkultur.

Adanya kebiasaan yang terus berkesinambungan satu sama lain, membuat $i$ KONIC lambat laun memiliki identitasnya sendiri yang dipegang secara individual maupun kelompok. Identitas sendiri merupakan suatu cara agar dapat menunjukkan suatu ciri-ciri, simbol, atau keadaan khusus yang mendasari tingkah laku yang kemudian akan menjadi suatu tombak pembeda suatu kelompok dengan kelompok lainnya.

Fanatisme yang mereka lakukan tiap hari dengan memandangi handphone, memiliki banyak koleksi barang berharga mahal, rela mengadakan project besar-besaran atau bahkan memfokuskan keuangan mereka untuk $i K O N$ merupakan sebuah ciri tersendiri yang menjadikan mereka memiliki identitas sebagai iKONIC. Aktivitas-aktivitas tersebut menjadikan suatu ciri identitas sosial tersendiri untuk para $i K O N I C$.

iKONIC bisa dikatakan sebagai suatu kelompok sosial, karena $i K O N I C$ adalah suatu sistem sosial yang terdiri dari sejumlah orang yang berinteraksi satu sama lain dan saling terlibat dalam suatu kegiatan bersama atau juga sekelompok orang yang mengadakan sebuah hubungan tatap muka secara berkala karena memiliki tujuan dan sikap bersama (Ibrahim, 2006).

Mereka memiliki tujuan utama yaitu untuk mencintai sang idola, untuk meraih rasa kepuasan fanatisme dan obsesinya untuk mencapai rasa ingin memiliki dalam segala hal yang berkaitan dengan sang idola. Hal tersebutlah yang menunjang para iKONIC memiliki ciri dan simbol tersendiri yang sangat dipengaruhi pula oleh $i K O N$. Dalam keadaan tersebut, lambat laun sebuah identitas terbentuk karena perilaku sehari-hari yang mereka laksanakan dan juga panutan yang mereka pegang.

\subsection{Korean Pop sebagai Identitas Subkultur iKONIC}

Dari sisi epistimologi, kata identitas berasal dari kata identity, yang berarti (1) kondisi atau sebuah keadaan nyata tentang sesuatu yang sama, suatu keadaan yang mirip satu sama lain; (2) kondisi dan fakta tentang sesuatu yang sama di antara dua atau lebih orang; (3) kondisi dan fakta yang menggambarkan sesuatu yang sama di antara dua orang atau lebih. Pengertian epistimologi di atas hanya sekedar menggambarkan tentang suatu kebiasaan untuk memahami apa itu identitas dengan kata 'identik', misal menyatakan A yang mirip dengan B (Liliweri, 2007).

Identitas sosial adalah sebagai ciri atau keadaan sekelompok masyarakat tertentu. Identitas menunjukkan cara individu atau kelompok dengan aktifitasnya yang dibedakan dengan individu atau kelompok dengan akfitas lainnya (Zaini, 2017). Identitas sendiri merupakan sesuatu yang terbentuk dari proses-proses sosial, mulai dari interaksi, kebiasaan, kemudian menjadi kesepakatan bersama yang terbentuk berangsur-angsur seiring berjalannya waktu. 
Identitas sosial adalah persamaan dan perbedaan, soal personal dan sosial, mengenai apa yang dimiliki bersama dengan orang lain dan apa yang juga membedakan dengan orang lain. Ketika membicarakan mengenai identitas maka sangat erat berkaitan dengan kelompok. Kelompok sosial sendiri adalah suatu sistem sosial yang terdiri dari sejumlah orang yang berinteraksi satu sama lain dan saling terlibat dalam suatu kegiatan bersama atau juga sekelompok orang yang mengadakan sebuah hubungan tatap muka secara berkala karena memiliki tujuan dan sikap bersama. Hubunganhubungan yang mereka jalin diatur oleh norma-norma, tindakan-tindakan yang dilakukan sesuai dengan kedudukan (status) dan peran (role) masing-masing dan memiliki ketergantungan satu sama lain (Ibrahim, 2006).

Hubungan satu sama lain antar iKONIC mulanya terbentuk karena adanya kontak sosial. Kemudian membangun sebuah reference group yang memiliki arti kelompok sosial yang menjadi ukuran bagi seseorang (bukan anggota kelompok) untuk membentuk pribadi dari perilakunya (Soekanto, 1981). Para anggota baru tidak perlu mendaftar secara resmi karena kelompok sosial yang dibangun oleh $i K O N I C$ berbentuk terbuka dan menerima siapa saja.

Berdasarkan penjelasan di atas, bisa dilihat bahwa identitas berkaitan dengan kelompok, dari situ dapat dilihat dalam keseharian mereka terbentuklah suatu kebiasaan-kebiasaan yang lambat laun melekat. Dengan adanya hal tersebut, identitaslah yang bertugas untuk membedakan satu kelompok atau bahkan juga individu dengan yang kelompok atau individu lain. Sama halnya juga $i K O N I C$, dalam kelompok atau subkultur ini memiliki suatu ciri khusus yang dapat dibedakan dari orang lain.

Dari konsep yang ada, subkultur merupakan sebuah gerakan aktivitas ataupun kegiatan dan kelakuan dari bagian culture yang besar. Biasanya bersifat melawan kebudayaan yang mainstream seperti agama, negara, institusi, gaya hidup dan lain-lain (Sari, 2017). Kemungkinan budaya mainstream yaitu seperti budaya asing yang menjadi dominan, contohnya budaya menggunakan celana jeans. Fenomena tersebut juga turut disertai dengan antusiame terhadap produk asing seperti $i K O N I C$ dan $i K O N$. Komunitas ini diduga tercipta karena adanya arus globalisasi yang mewujudkan sebuah subkultur.

John Storey berpendapat bahwa konsumsi suatu budaya populer akan mengakibatkan kemunculan kelompok penggemar, dia menyatakan "penggemar adalah bagian paling tampak dari khalayak teks dan praktik dari budaya pop" (Storey, 2007:157). Musik K-Pop sendiri berhasil mengumpulkan banyak fans dari berbagai penjuru dunia, seperti iKONIC untuk boygroup $i K O N, i K O N I C$ berasal dari berbagai tempat yang kemudian disebut dengan fandom.

Simbol-simbol juga diterangkan oleh Geetrz (1973) dalam penjelasannya mengenai interpretivisme simbolik bahwa, kebudayaan merupakan sistem keteraturan makna dan simbolsimbil. Melalui makna dan simbol tersebut, setiap individu berkomunikasi, menetapkan, dan mengembangkan pengetahuan tentang kehidupan dan menyikapi kehidupan (Geertz dalam Irinto, 2009). Simbolik itu sendiri sebagai pengontrol perilaku.iKONIC menginterpretasikan perilakunya sebagai fans dari $i K O N$. Mereka memiliki fanatisme, menurut dengan perkataan $i K O N$, berkomunikasi dengan $i K O N$ dan sesama $i K O N I C$, bahkan simbol yang terlihat jelas seperti KONBAT, merchandise, dan lain sebagainya.

Disisi lain, Barker pernah mengemukakan pendapatnya mengenai identitas. Dia mengatakan bahwa identitas adalah seluruh aspek sosial dan kultural. Jadi identitas sepenuhnya merupakan konstruksi sosial (Barker, 2008). Identitas sendiri dapat diekspresikan melalui selera, sikap, kepercayaan, gaya hidup dan kegemaran.

Dari keterangan-keterangan di atas dapat dilihat bahwa identitas dan simbol dapat diketahui dari segala bentuk ekspresi diri yang dimunculkan dalam praktik ideologi (sistemkeyakinan). Praktik-praktik itu pun dapat ditemukan dari para iKONIC dalam perilaku kesehariannya, 
bagaimana cara mereka menghabiskan waktu dan juga menghabiskan uangnya. Bahkan mereka sendiri memiliki prinsip-prinsip yang tertanam dari sang idol yaitu $i K O N$, perkataan sang idola yang mereka anut akan membentuk suatu identitas tersendiri yaitu sebuah subkultur.

Pembeda yang nampak nyata juga disebabkan dari $i K O N$ sendiri yang menanamkan banyak prinsip kepada penggemarnya, atribut dan banyak kegiatan yang dilaksanakan. Pernah dikatakan oleh Kim Donghyuk, salah satu member $i K O N$ yang berkata bahwa KONBAT dipergunakan khusus untuk mereka $(i K O N)$ saat event yang berkaitan dengan $i K O N$ sedang berlangsung. Keadaan tersebut menanamkan sebuah prinsip dan aturan yang akan ditetapkan ke depannya. Hal itu dapat terlihat di saat konser festival K-POP. Para $i K O N I C$ akan menggunakan KONBAT yang membedakannya dari fandom atau subkultur lain.

Terbentuknya identitas $i K O N I C$ bermula dari Budaya K-Pop $(i K O N)$ yang tersebar melalui media massa seperti majalah, koran, radio, dan terutama internet yang kemudian menyebabkan timbulnya suatu kontak sosial yang terjadi antara sesama individu yang menggemari K-Pop ( $i K O N)$. Dari situlah terjadi proses learn yang akan terus bertimbal balik dengan kontak sosial, menyebabkan suatu individu akan belajar untuk mengetahui apa saja yang ada didalam kebudayaan K-Pop $(i K O N)$. Mereka akan memahami kemudian akan menerapkannya yang menjadi sebuah sistem kognisi. Individu akan bergabung kepada komunitas iKONIC yang kemudian akan menyamakan atribut, baju, kebiasaan sehari-hari yang cenderung sama satu sama lain dan rutin dilakukan setiap harinya. Melalui atribut, baju, kebiasaan-kebiasaan yang mereka lakukan tiap harinya, terbentuklah sebuah simbol yang menjadikan ciri khas untuk para penggemar K-Pop $(i K O N)$ ini yang dapat membedakan dari komunitas lainnya.

Melalui keadaan ini, terjadilah sistem share atau berbagi kepada sesama penggemar maupun membagikan kepada individu atau kelompok bukan penggemar agar dapat mengetahui bahwa budaya K-Pop itu ada dan mampu diikuti oleh semua kalangan. Kemudian tindakan kolektif akan terjadi seiring berjalannya waktu untuk memenuhi hasrat kepuasan yang ada, seperti melakukan streaming lagu, membeli atribut, dan bahkan hal yang mahal sekalipun seperti menonton konser. Hal hal tersebut yang akan membentuk sebuah identias yaitu identitas sebagai $i K O N I C$ yang merupakan penggemar dari boygroup iKON yang kemudian akan mencerminkan dari sebuah kebudayaan K-Pop.

\section{Simpulan}

Identitas yang terbentuk dari para $i K O N I C$ sebagai kesatuan subkultur memiliki asal usul yang beragam. Tapi semua kebanyakan berawalan dari peran media massa yang begitu cerpat menyebar dan mempengaruhi para penikmat budaya pop. iKONIC secara kolektif membentuk identitasnya melalui semua aktiftas yang dilakukan dalam kesehariannya.

$i K O N I C$ yang fanatik, tergila-gila, menjadikan $i K O N$ sebagai panutan dan bahkan menjadikan $i K O N$ sebagai contoh pedoman dalam bertindak. Di samping itu, para $i K O N I C$ juga mengumpulkan barang-barang yang pastinya bernilai sangat mahal. Hal tersebut semata-mata mereka lakukan untuk merasa lebih dekat dengan sang idola dan memenuhi hasrat kepuasan dalam memiliki. Sesuatu yang mereka kumpulkan seperti album musik, poster, tas, foto, kaos, slogan, majalah dan lain-lain akan disimpan di dalam tempat yang rapat dan rapih agar tidak berdebu ataupun hilang. Ada juga yang lebih memilih untuk di pajang untuk memenuhi hasrat kepuasan dalam mengoleksi barang-barang tersebut.

Semua hal yang mereka dapatkan termasuk tiket konser atau fan meeting dilakukan dengan cara bekerja dan menabung sampai pada titik darah penghabisan. Mereka rela untuk tidak makan 
bahkan untuk sekedar membeli baju demi mendapatkan kepuasan yang mereka inginkan yang berkaitan dengan sang idola. Bahkan tidak sedikit pula yang memanfaatkan keadaan dengan membuka sebuah pekerjaan sendiri yang berkaitan dengan sang idola yang nantinya juga dihabiskan penghasilannya untuk sang idola kembali. Contohnya membuat kaos, topi, tas yang bernuansa $i K O N$ yang kemudian di perjual belikan pada kerabat $i K O N I C$ sendiri lalu hasil keuntungan dari usahanya tersebut akan ditabung untuk bertemu dengan sang idola atau memberi barang-barang lainnya yang berkaitan dengan sang idola.

Di balik ini semua, para remaja $i K O N I C$ sebenarnya memilih $i K O N$ sebagai idola karena ingin menunjukkan eksistensi yang mereka miliki. Mereka ingin menunjukkan bahwa iKONIC juga memiliki kebudayaan, aktifitas, ciri-ciri, gaya hidup, aturan, tingkah laku, dan kesenangan yang khusus mereka miliki untuk diri mereka sendiri bersama dengan komunitasnya. Hal inilah yang dapat membedakan subkultur $i K O N I C$ dengan subkultur lainnya.

Idola jelas menjadi suatu tempat untuk menunjukkan keberadaan gaya hidup dan kebudayaan para $i K O N I C$. Penyebaran kebudayaan tersebut juga tidak lepas dari peran media massa. Justru disini media massa sangat berperan besar untuk penyebaran dan pertukaran informasi dengan cara yang efektif. Media massa merupakan salah satu produsen makna pembentuk idola dengan berbagai citra dan gaya hidup yang di inginkan para remaja. Citra tersebut di tunjukkan iKON melalui perunjukan musik, video clip, kisah hidup mereka, iklan dan lain-lain.

Sebagai salah satu gambaran produk hiburan berserta citra yang mereka bawa, iKON mempunyai kegunaan sebagai sebuah petunjuk identitas. iKONIC dapat menggunakan $i K O N$ untuk menunjukkan identitas mereka lewat kegemaran, gaya hidup dan fanatisme yang mereka lakoni. iKON secara tidak langsung menjadi salah satu jembatan untuk mengidentifikasi diri.

$i K O N$ dan citranya juga digunakan para $i K O N I C$ untuk menunjukkan identitas mereka yang akhirnya $i K O N$ memiliki kegunaan untuk tempat belajar dan panutan dalam keseharian iKONIC dalam melakukan aktikfitasnya. Banyak hal yang di pelajari seperti kerja keras harus di lakukan untuk meraih cita-cita, tutur kata dan bahasa, tingkah laku, maupun gaya hidup. Para iKONIC merasa bahwa $i K O N$ tidak pernah memberi dampak negatif dan tidak pernah merugikan pihak manapun.

Identitas yang terbentuk menjadi suatu yang dapat mewakili dan juga menggambarkan jati diri seorang iKONIC. Dengan adanya kebiasaan-kebiasaan yang timbul tiap harinya, hasrat keinginan untuk terus ingin dekat dengan idolanya, dan juga ajaran-ajaran yang disampaikan oleh iKON membuat identitas $i K O N I C$ terbentuk secara perlahan namun pasti.

Penerapan perilaku yang di ajarkan oleh $i K O N$ tentunya menjadi sebuah ciri khas tersendiri, di tambah pula kebiasaan sehari-hari $i K O N I C$ yang berbeda dari penggemar budaya pop lainnya. Pembentukan identitas sendiri terjadi karena adanya proses kesepakatan bersama antara para iKONIC yang terus melakukan interaksi secara teratur, atribut atau dress code yang sudah ditetapkan selama kegiatan berlangsung, dan juga tentunya sistem keteraturan yang diajarkan oleh iKON yang kemudian di anut oleh iKONIC. Interaksi yang terjadi seiring waktu juga akan memunculkan kebiasaan-kebiasaan yang hanya muncul di kalangan para iKONIC. Pada saat iKONIC menerapkan sistem budaya, atribut dan kebiasaan mereka, hal ini lah yang mencerminkan identitas $i K O N I C$ sebagai subkultur yang terbentuk karena $i K O N$.

Identitas tersebut juga menjadi sebuah wujud ekspresi para iKONIC untuk memperlihatkan diri sebagai salah satu subkultur yang memiliki eksistensi. Selain sebuah kebiasaan, iKONIC juga memiliki banyak atribut yang mencerminkan identitas mereka seperti contohnya adalah KONBAT. Keberadaan mereka tetap akan ada selama $i K O N$ masih didalam bagian dari budaya pop. 


\section{Daftar Pustaka}

Barker, Chris. 2008. How Social Media is Transforming Employee Communications at Sun Microsystems, Global Business and Organizational Excellence, Vol. 27 (4): 6-14. https://blogs.aalto.fi/stratusreader/2012/04/23/barker-p-2008-how-social-media-istransforming-employee-communications-at-sun-microsystems-global-business-andorganizational-excellence-vol-27-4-pp-6-14/, (akses 20 Juli 2018).

Deffleur, dkk. 1985. Understanding Mass Communication, Boston: Houghbon Mifflin Company. Geertz, Clifford. 1973. The Interpretation of Cultures. New York: Basic Books.

Hollows, Joanne. 2000. Feminisme, Feminitas dan Budaya Populer. Yogyakarta: Jalasutra.

Ibrahim. 2006. Kritik Budaya Komunikasi: Budaya, Media dan Gaya Hidup dalam Proses Demokratisasi di Indonesia. Yogyakarta : Jalasutra.

Irianto, Agus. 2009. Epistimologi Kebudayaan. Isu Teoritik dalam Karya Etnografi. Semarang: Lengkongcilik Press.

Joang, Hae. 2005. "Reading the 'Korean Wave' as a Sign of Glikbal Shift". Academia. Vol. 45 (4): 167.

https://www.academia.edu/29153429/Reading_the_Korean_Wave_as_a_Sign_of_Global_Sh ift, (akses 26 Juli 2018).

Liliweri. 2003. Makna Budaya Dalam Komunikasi Antar Budaya. Yogyakarta: LkiS.

Puspitasari, Wulan, dkk. 2013. "Gaya Hidup Penggemar K-Pop (Budaya Korea) Dalam Mengekspresikan Kehidupannya Studi Kasus K-Pop Lovers Di Surakarta." https://eprints.uns.ac.id/1194/ (akses 25 Juni 2018).

Spradley, James. 1997. Metode Etnografi, Elizabeth, penerjemah. Yogyakarta: Tiara Wacana.

Storey, John. 2007. What is Cultural Studies? A Reader. Sunderland: Bloomsbury Academic.

Subhan, Arif. 2013. "Identitas Budaya dan Komunikasi Antarbudaya". http://repository.usu.ac.id/bitstream/handle/123456789/29403/Chapter\%20II.pdf?sequence= 4\&isAllowed=y, (akses 19 Juli 2018).

Sulaeman. 2012. Sistem Sosial dan Sistem Budaya. Ilmu Sosial Budaya Dasar. Bandung: Refika Aditama.

Suprayogi, Wiji. 1998. "Alasan Pemilihan dan Kegunaan Idola Dari Dunia Muwsik Populer Bagi Remaja 'Empat Remaja Condongcatur'” Skripsi Sarjana Program Studi Antropologi Universitas Gajah Mada Yogyakarta. 